\title{
O uso interativo da comunicação em crianças autistas verbais e não verbais***
}

\author{
Interactive use of communication by verbal and non-verbal autistic \\ children
}

\author{
Cibelle Albuquerque de la Higuera Amato* \\ Fernanda Dreux Miranda Fernandes**
}

\author{
*Fonoaudióloga. Doutora em Semiótica \\ e Linguística Geral pela Faculdade de \\ Filosofia, Letras e Ciencias Humanas da \\ Universidade de São Paulo (USP). \\ Fonoaudióloga do Departamento de \\ Fisioterapia, Fonoaudiologia e Terapia \\ Ocupacional da Faculdade de Medicina \\ da Universidade de São Paulo \\ (FMUSP). Endereço para \\ correspondência: \\ R. Cipotanea, 51 - São Paulo - SP - \\ CEP 05360-160 \\ (cibelleamato@usp.br). \\ **Livre-Docente em Fonoaudiologia \\ pela FMUSP. Professora Associada do \\ Departamento de Fisioterapia, \\ Fonoaudiologia e Terapia Ocupacional \\ da FMUSP. \\ ***Trabalho Realizado no \\ Departamento de Fisioterapia, \\ Fonoaudiologia e Terapia Ocupacional \\ da FMUSP.
}

Artigo Original de Pesquisa

Artigo Submetido a Avaliação por Pares

Conflito de Interesse: não

Recebido em 21.06.2010.

Revisado em 30.09.2010.

Aceito para Publicação em 29.10.2010.

\begin{abstract}
Background: communication of autistic children. Aim: to assess the communication functionality of verbal and non-verbal children of the autistic spectrum and to identify possible associations amongst the groups. Method: subjects were 20 children of the autistic spectrum divided into two groups: $\mathrm{V}$ with 10 verbal children and NV with 10 non-verbal children with ages varying between $2 \mathrm{y} 10 \mathrm{~m}$ and $10 \mathrm{y} 6 \mathrm{~m}$. All subjects were video recorded during 30 minutes of spontaneous interaction with their mothers. The samples were analyzed according to the functional communicative profile and comparisons within and between groups were conducted. Results: data referring to the occupation of communicative space suggest that there is an even balance between each child and his mother. The number of communicative acts per minute shows a clear difference between verbal and non-verbal children. Both verbal and non-verbal children use mostly the gestual communicative mean in their interactions. Data about the use of interpersonal communicative functions point out to the autistic children's great interactive impairment. Conclusion: the characterization of the functional communicative profile proposed in this study confirmed the autistic children's difficulties with interpersonal communication and that these difficulties do not depend on the preferred communicative mean.
\end{abstract}

Key Words: Autistic Disorder; Child; Language.

\section{Resumo}

Tema: comunicação de crianças autistas. Objetivo: avaliar a funcionalidade da comunicação de crianças incluídas no espectro autístico divididas em dois grupos (verbais e não verbais) e identificar as possíveis relações entre os grupos estudados. Método: foram sujeitos 20 crianças autistas, 10 verbais e 10 não verbais, com idade variando entre 2a e $10 \mathrm{~m}$ e $10 \mathrm{a}$ e $6 \mathrm{~m}$ de vida. Todos os sujeitos foram gravados durante 30 minutos, em situação de interação espontânea com a mãe. O corpus das gravações dos dois grupos foi analisado quanto ao desempenho do perfil funcional de comunicação de cada sujeito, de cada grupo e as possíveis relações existentes entre os dois grupos. Resultados: os dados referentes à ocupação do espaço comunicativo sugerem equilíbrio entre a comunicação da criança autista e sua mãe. Quanto ao número de atos comunicativos produzidos por minuto, nota-se que há uma visível divisão entre as crianças, que coincide com a divisão de grupos proposta: crianças autistas verbais e crianças autistas não verbais. Com relação à utilização dos meios comunicativos pelas crianças autistas observa-se que tanto as crianças autistas não verbais como as verbais fazem grande uso do meio gestual para se comunicarem. Os dados correspondentes à utilização das funções comunicativas mais inter-pessoais apontam a dificuldade da criança autista em interagir com o outro Conclusão: a caracterização do perfil funcional da comunicação realizada neste estudo confirmou a dificuldade destas crianças no estabelecimento de interações comunicativas e como essas dificuldades independem do meio comunicativo utilizado.

Palavras-Chave: Transtorno Autístico; Linguagem; Criança.

Referenciar este material como: 


\section{Introduction}

Infantile autism is considered a developmental disorder that reaches the areas of social interaction, language and cognition. The autism spectrum includes a wide range of neurodevelopmental disorders whose central axles involves three great areas: social interaction impairments, verbal and non-verbal communication disorders and restrict and repetitive patterns of behavior1. The pragmatic perspective involves the functional aspects of language: including non-verbal, social and environmental issues in the study of language; determining associations between language and context and considering the language development as related to the child's cognitive, emotional and social development2. According to the author, the pragmatic theories allow the focus on the language's social value. The communication of children of the autism spectrum has several peculiarities and doesn't follow the same developmental course observed in normal children. Several authors report comparative studies with children in normal development, with mental deficits or with specific language impairments3-7. Another author8 states that mothers of autistic children tend to speak directly toward the child's attention focus as frequently as mothers of children with typical language development. The mother's adaptation attempts to the child's interaction impairments were also identified in a previous study9. A research about the gaze direction of autistic children produced results very similar to four-month old babies10. Longitudinal studies favor the identification of individual and comparative variations in language development of autistic children11. A study about the interactive stile of autistic children's mothers indentified that the mothers that deal better with the diagnosis tend to establish more effective communicative interactions12.

The aim of this study was to compare the communicative functionality of verbal and nonverbal autistic children.

\section{Method}

This study was approved by the institution's ethic committee (\#347/97) and al the caretakers signed the consent form.

\section{Subjects}

Subjects of this study were 20 autistic children with ages varying from 2:10 to 10:6, 17 of male gender and 3 females with diagnosis of autism spectrum disorders determined by psychiatrists according to the criteria determined by the American Psychiatry Association in the DSM-IV13 and by the World Health Organization in the IDC14 and referred to speech and language assessment.

Procedures

All subjects were divided in two groups (verbal and non-verbal) filmed just once before the language assessment. The inclusion criteria in the verbal (V-10 subjects) or in the non-verbal (NV-10 subjects) groups was the medical report included in the referral documents. None of the subjects had gone to prior speech and language assessment intervention before the study's onset. All subjects were filmed for 30 minutes during a situation of spontaneous play with their mothers. The recording took place in the same laboratory the children received language therapy after the initial assessment (SLP research laboratory in ASD School of Medicine - Universidade de Sao Paulo). No special instructions were provided to mothers or children. It was performed by one of the researchers or by the speech and language pathologist that would conduct the posterior assessment in a time and date previously accorded with each mother. The filmed samples were synthesized in individual protocols that identified: the number of communicative acts produced per minute, the communicative functions expressed and the communicative means used according to the criteria suggested by Fernandes1. The whole corpus was analyzed about the functional communicative profile of each subject, of each group and the possible associations between the groups.

\section{Results}

To this study the t-student test was used with a significance level of 5\% (0.050).

The proportion of occupation of the communicative space, presented in Table 1, was close to $40 \%$, with the largest variations in the NV group. Non-verbal autistic children (NV group) presented variations between $25 \%$ and $63 \%$ while in the verbal autistic children (V group) the variation was between $29 \%$ and $49 \%$. Different from the communicative space, the number of communicative acts produced per minute resulted in a significant difference between the groups. Non-verbal autistic children produced less communicative acts per 
minute than the verbal children.

The next analysis refers to the use of the different communicative means. Table 2 shows that in both groups the gestural communicative mean was the most frequently used. This was the only communicative mean that didn't present significant differences between the groups. It is important to point out that children of group $\mathrm{V}$ have verbal communication and even so only four of them used more frequently the verbal than the gestural communicative mean. It should be stressed that among the non verbal autistic children the gestural mean is the most frequent followed by the vocal mean while in the group of verbal autistic children the vocal mean is less expressive and the verbal mean is more used. The use of the gestural mean in significant in both groups.

Table 3 presents the data referring to the interpersonal communicative functions expressed, that is, the proportion of communication interactivity. It can be noted that just two children of the NV group didn't use any interpersonal communicative function and just one of the $\mathrm{V}$ group expressed only interactive communicative acts during data gathering. Although there is a significant difference between the groups, the low proportion of interactive communicative acts in the communication of autistic children is an issue that will be retaken in the discussion of the results.

TABLE 1. Proportion of the communicative space occupied and number of communicative acts per minute expressed by the subjects of the two groups

\begin{tabular}{ccc|ccc} 
Subjects & $\begin{array}{c}\text { Non-Verbal Group } \\
\text { Communicative } \\
\text { space \% }\end{array}$ & Acts/minute & Subjects & $\begin{array}{c}\text { Verbal Group } \\
\text { Com municative } \\
\text { space \% }\end{array}$ & Acts/minute \\
\hline 1 & 63 & 3.2 & 11 & 38 & 6.7 \\
2 & 47 & 2.4 & 12 & 45 & 3.8 \\
3 & 25 & 1.3 & 13 & 49 & 3.9 \\
4 & 50 & 3.4 & 14 & 31 & 5.1 \\
5 & 37 & 1.6 & 15 & 34 & 6.3 \\
6 & 34 & 1.4 & 16 & 38 & 7.2 \\
7 & 39 & 1.9 & 17 & 29 & 3.3 \\
8 & 47 & 1.8 & 18 & 32 & 4.5 \\
9 & 48 & 1.8 & 19 & 31 & 3.4 \\
10 & 34 & 1.6 & 20 & $37 \%$ & 4.89 \\
Average & $42.4 \%$ & 2.04 & Average & 6.44 & 0.33 \\
St. deviation & 10.2 & 0.69 & St. deviation & (p) & 0.19612 \\
\hline
\end{tabular}

TABLE 2. Proportion of use of the com municative means by the subjects of both groups

\begin{tabular}{|c|c|c|c|c|c|c|c|}
\hline \multicolumn{4}{|c|}{ Non-Verbal Group } & \multicolumn{4}{|c|}{ Verbal Group } \\
\hline Subjects & VE & VO & $\mathrm{G}$ & Subjects & VE & VO & G \\
\hline 1 & 0 & 37 & 63 & 11 & 37 & 21 & 51 \\
\hline 2 & 0 & 48 & 53 & 12 & 18 & 26 & 60 \\
\hline 3 & 0 & 25 & 75 & 13 & 40 & 13 & 49 \\
\hline 4 & 1 & 47 & 52 & 14 & 6 & 19 & 79 \\
\hline 5 & 0 & 54 & 48 & 15 & 24 & 11 & 69 \\
\hline 6 & 2 & 15 & 83 & 16 & 53 & 24 & 33 \\
\hline 7 & 7 & 21 & 73 & 17 & 62 & 3 & 41 \\
\hline 8 & 7 & 44 & 49 & 18 & 60 & 2 & 40 \\
\hline 9 & 0 & 21 & 81 & 19 & 57 & 8 & 41 \\
\hline 10 & 0 & 6 & 94 & 20 & 37 & 3 & 64 \\
\hline Average & 1.7 & 31.8 & 67.1 & Average & 39.4 & 13 & 52.7 \\
\hline St. deviation & 3.09 & 16,29 & 16.33 & St. deviation & 19.00 & 9.06 & 14.82 \\
\hline & & & & (p) & 0.0427 & 0.0049 & 0.1134 \\
\hline
\end{tabular}

Legend: VE = verbal; $\mathrm{VO}=$ vocal; $\mathrm{G}$ = gestural 
TABLE 3. Proportion of co mmunication interactivity of subjects of both groups

\begin{tabular}{cccc} 
Subjects & $\begin{array}{c}\text { Non-Verbal Group } \\
\text { Interpersonal functions \% }\end{array}$ & $\begin{array}{c}\text { Verbal Group } \\
\text { Interpersonal functions \% }\end{array}$ \\
\hline 1 & 50 & 11 & 50 \\
2 & 56 & 12 & 50 \\
3 & 0 & 13 & 63 \\
4 & 40 & 14 & 60 \\
5 & 50 & 15 & 63 \\
6 & 25 & 16 & 64 \\
7 & 25 & 17 & 64 \\
8 & 50 & 18 & 56 \\
9 & 25 & 19 & 50 \\
10 & 0 & 20 & 63 \\
Average & 32.1 & Average & 58.3 \\
St. deviation & 19.51 & St. deviation & 5.88 \\
& & (p) & 0.0077 \\
\hline
\end{tabular}

\section{Discussão}

The analysis of the occupation of communicative space and of the number of communicative acts produced per minute by the subjects of this research shows variations in both aspects. The occupation of the communicative space indicates a certain balance in the motherchild communication. However, when the production of communicative acts is considered in relation to the sample's duration the data about both groups are different suggesting that the reciprocity between mother and child forms the base and the mold from which communication develops. In the first aspect, communicative space occupation, the mother seems to be the agent of the balance. The interactive situation is a privileged one because each child has the own mother as a communicative partner. Knowing the child's communicative needs the mother works as a facilitator to the communication and places the child as the central focus of her attention (at least during the data gathering period). Prior studies46,16-18 point out to the mother's important as a communicative partner to the communication development process. The mother represents a preferred partner to the child, determining an affective association that will generate symmetric communication patterns19. Other authors18 state that the mothers use simple, repetitive speech, grammatically and semantically adjusted to the child1s understanding and interest levels. In this sense, the largest data dispersion referring to the non-verbal children with more than 3 years of age shows how difficult is this process undertaken by the mother, of building a symmetric communication and therefore of building her own role as a communicative partner. In the second aspect, the number of communicative acts expressed per minute, the relation if the communication produced by the child within a certain time lapse and it can be a good indicator of the communicative performance.

In this aspect it can be noted that there is a clear division between the groups. Even not expecting any chronological association, these data allow the consideration of the verbal group as further developed than the non-verbal one in term of communication development since the best performance of the $\mathrm{V}$ group practically coincides with the poorest performance of the NV group.

In what refer to the use of the communicative means by autistic children, it was observed that both the verbal and the non-verbal children use mostly the gestural mean of communication. The subjects of the NV group used the vocal communicative mean more than the subjects of the $\mathrm{V}$ groups. Brazilian authors20 compared the pragmatic abilities in normally developing children and in children with language developmental disorders and verified that the children with language developmental disorders presented impairments or delays in the preferential use of the verbal mean to communicate and used more gestures and vocalizations to express communicative intent. According to the authors the prevalence or stability of the use of gestural and vocal communicative means may be suggestive of impairments in language development. 
A prior research21 studied the communication of autistic children in different contexts and observed variations in the use of the different communicative means according to the communicative partner. According to the authors when the interlocutor in less efficient (in the case of this study, a group situation without an adult's facilitation) the use of redundant communicative means is necessary, and so the gestural means may support what is conveyed by the verbal mean, for example. It follows the same principle determined in the present study.

The analysis of the use of the interpersonal communicative functions provides data about the child's interactive competence and the data presented show the autistic children's impairment in this domain. This observation confirms prior studies8 that concluded that autistic children are less responsive to interactive attempts and have less spontaneous communication. Other studies6,22-24 report the severe impairment of autistic children in the interactive use of communication to specific functions.

\section{References}

1. Fernandes FDM.Pragmatica. In: Andrade CRF; BefiLopes DM; Fernandes FDM, Wertzner HF. ABFW, teste de linguagem infantil nas áreas de fonologia, vocabuilário, fluência e pragmática. Carapicuiba, Pró-Fono; 2004. (cap 4). p. 90

2. Fernandes FDM. Autismo Infantil - repensando o enfoque fonoaudiológico - aspectos funcionais da comunicação. São Paulo: Lovise; 1996. p. 96.

3. Chawarska K, Paul R, Klin A, Hannigen S, Dichtel LE, Volkmar F. Parental recognition of developmental problems in toddlers with autism spectrum disorders. J Autism Dev Disord. 2007;37(1):62-72.

4. Clifford SM, Dissanayake C. The early development of joint attention in infants with autistic disorder using home video observations and parental interview. J Autism Dev disord. 2008;38(4):791-805

5. Solomon M, Ono M, Timmer S, Goodlin-Jones B. The effectiveness of parent-child interaction therapy for families of children on the autism spectrum. J Autism Dev Disord. 2008;38(7):1767-76.

6. Laugerson EA, Frankel F, Mogil C, Dillon AR. Parentassisted social skills training to improve friendships in teens with autism spectrum disorders. J Autism Dev Disord. 2009;39(3):596-606.

7. Williams E, Kendell-Scott L, Costall A. Parents' experiences of introducing everyday object use to their children with autism. Autism. 2005;9(5):495-514.

\section{Conclusion}

The difficulties presented by autistic children with the interactive use of communication reinforces the meaning of the notion that isolated and specific social and cognitive elements evolve together with the linguistic and non-linguistic communication development and there is a mutual interference in the process. Therefore the inclusion of the autism as a developmental disorder makes sense since it involves all the areas of development.

The option of conducting the data gathering in communicative situations with the mothers provided a familiar interlocutor that probably allowed each child's best performance. The characterization of the functional communicative profile confirmed the areas of larger difficulties. The presence of large individual differences demands other studies comparing more homogeneous groups.
8. Watson LR, Baranek GT, Crais ER, Reznick JS, Dykstra J, Perryman T. The first year inventory: retrospective parent responses to a questionnaire designed to identify one-year-olds at risk for autism. J Autism Dev Disord. 2007;37(1):49-61.

9. Amato CAH. Estudo comparativo dos processos de aquisição da linguagem não verbal em crianças pré-verbais autistas e normais [dissertação]. São Paulo: Faculdade de Medicina, Universidade de São Paulo; 2000.

10. Grice SJ, Halit H, Baron-Cohen S, Bolton P, Johnson MH. Neural correlates of eye-gaze detection in young children with autism. Cortex. 2005;41(3):342-53.

11. Tager-Flusberg H. Strategies for conducting research on language in autism. J Autism Dev Disord. 2004;34(1):7580 .

12. Wachtel K, Carter AS. Reaction to diagnosis and parenting styles among mothers of young children with ASDs. Autism. 2008;12(5):575-94.

13. American Psychiatric Association. Manual de Diagnóstico e Estatística de Distúrbios Mentais. DSM-IV. São Paulo: Manole; 1994. p. 880.

14. Organização Mundial de Saúde. Classificação de transtornos mentais e de comportamento do CID - 10 . Porto Alegre: Artes Médicas; 1993. p. 262.

15. Maxwell DL, Satake E. Ressearch and statistical methods in communicationsciences and disorders. Canada: Thomson Delmar Learning; 2006. p. 118. 
16. Ruser TF, Arin D, Dowd M, Putnam S, Winklosky B, Rosen-Sheidley B, Piven J, Tomblin B, Tager-Flusberg H, Folstein S. Communicative competence in parents of children with autism and parents of children with specific language impairment. J Autism Dev Disord. 2007;37(6):1323-36.

17. Reed P, Osborne LA, Corness M. Brief report: relative effectiveness of different home-based behavioral approaches to early teaching intervention. J Autism Dev Disord. 2007;37(7):1815-21.

18. Benson P, Karlof KL, Siperstein GS. Maternal involvement in the education of young children with autism spectrum disorders. Autism. 2008;12(1):47-63.

19. Fernandes FDM. Diagnóstico e terapia de linguagem com crianças com transtornos do espectro autístico. In: Fernandes FDM, Mendes BCA, Navas ALGP. Tratado de Fonoaudiologia. São Paulo: Roca; 2009. p. 362-72. 836p.
20. Rodrigues A, Befi-Lopes DM. Comparação entre as habilidades pragmáticas de crianças normais e crianças com alteração de desenvolvimento de linguagem. Rev. Soc. Bras. Fonoaudiol. 2004;9(2):81-7.

21. Cardoso C; Fernandes, FDM . Relação entre os aspectos sócio cognitivos e perfil funcional da comunicação em um grupo de adolescentes do espectro autístico. Pró-Fono, Barueri. 2006;18(1):89-98.

22. Scheeren AM, Stauder JEA. Broader autism phenotype in parents of autistic children: reality or myth? J Autism Dev Disord. 2008;38(1):276-87.

23. Davis NO, Carter AS. parenting stress in mothers and fathers of toddlers with autism spectrum disorders: associations with child characteristics. J Autism Dev Disord. 2008;38 (7):1278-91.

24. Grindle CF, Kovshoff H, Hastings RP, Remington B. Parents' experiences of home-based applied behavior analysis programs for young children with autism. J Autism Dev Disord. 2009;39(1):42-56. 